\title{
Schooling and Poor Children in 19th-Century America
}

\author{
MARIS A. VINOVSKIS \\ University of Michigan
}

Societies are always confronted with the problem of dealing with poor children. Often, this means finding ways of overcoming or compensating for the disadvantaged backgrounds of these children. Indeed, concem about the fate and well-being of disadvantaged children in the United States today has lead many policymakers to look once again to the schools for assistance.

Despite our strong and persistent belief in the importance and necessity of education in preparing future citizens, not everyone agrees that American schools are designed or prepared to help disadvantaged children. Some contend that family background rather than the quality of the school is the main determinant of student achievement and of subsequent job placement (Jencks, 1979). Although these scholars acknowledge that the total amount of schooling received matters, they argue that the length of schooling is more dependent on a child's home environment than on the school setting. Other analysts have gone even further to argue that public schools in 19th-century America were deliberately designed to perpetuate the existing inequalities within the expanding capitalist economy (Bowles \& Gintis, 1976; Katz, 1975). Rather than helping poor students in the past or today, these critics argue that the school system was created in large part to allow middle- or upper-class parents to help their own children while ensuring that those from disadvantaged backgrounds would not advance.

To investigate the relationship between schooling and poor children historically, this article examines the origins and development of 19thcentury education in the United States with particular attention to whether or not schools helped poor children obtain better jobs. First, the establishment and expansion of schools in the early 19th century are analyzed. Next, contemporary views of schooling and poor children are noted and their ideas about the relationship between education and economic productivity exAMERICAN BEHAVIORAL SCIENTTST, Vol. 35 No. 3, January/February 1992 313-331 O 1992 Sage Publications, Inc. 
plored. Then, the article looks at three antebellum educational reforms intended to help poor children: (a) monitorial charity schools, (b) Sunday schools, and (c) infant schools. Doing so allows us to assess to what extent early 19th-century Americans were interested in dealing with the problems and needs of poor children. In addition, school attendance among poor children is investigated to see if they were excluded from these new institutions as some historians have claimed. Finally, the important question of whether or not schooling actually fostered occupational mobility among poor children is addressed.

By examining the development of schooling in the United States in the 19 th century and its impact on poor children, we can ascertain the intentions and evaluate the achievements of early efforts to deal with disadvantaged children in our society. We analyze the relative roles of parents and schools in educating children and assess the importance of schooling in fostering social mobility in the past. Furthermore, by investigating the different ways in which school reformers tried to alleviate the problems associated with poverty among 19 th-century children, we can place our current educational reforms in a broader historical perspective.

\section{EXPANSION OF SCHOOLING IN THE 19TH CENTURY}

Schools have not always been the primary institutions for socializing and training children. In colonial New England, the household had the primary responsibility for educating children and servants (Bailyn, 1960). Ministers and churches were expected to assist the household since the goals of education were primarily religious. Initially, the father rather than the mother was entrusted with the education and catechizing of the children in the home. Only after the mid-17th century, when males stopped joining the New England churches as a matter of course, did Puritans slowly and reluctantly turn to women as the chief agents for home education (Moran \& Vinovskis, 1986).

Even if parents were expected to educate their own children and servants at home, they sometimes used schools to assist them. Older women, often widows, set up dame schools to educate young children (Cremin, 1970). In some communities private elementary schools were created to cater to those parents who did not want to educate their own children at home (Murphy, 1960). In addition, the few children who continued their education beyond the rudiments of reading and writing went to grammar schools established in the larger communities (Vinovskis, 1987). Increasingly, during the colo- 
nial period, parents placed their children in private or public schools whenever they became available in the local communities, but at least one scholar (Cohen, 1974) has argued that opportunities for formal education may have actually declined in the 18 th century.

One of the major changes in 19th-century American life was the development of mass public elementary or common schools. Yet there is considerable disagreement on when or why this occurred. In the 1960s and 1970s, a group of scholars, sharply critical of the existing educational system, reexamined the origins of American schooling and concluded that common schools were established as a response to industrialization (Bowles \& Gintis, 1976; Katz, 1968). These historians, often designated as "revisionists," argued that manufacturers and merchants spearheaded the public school expansion and reforms to instill in future workers a respect for law and authority necessary in the newly emerging capitalist economy (Bowles \& Gintis, 1976, pp. 178-179).

The revisionists' particular focus on Massachusetts parallels the concentration of other scholarship on the educational and economic developments in that state. This is significant because the Commonwealth was not only a leader in educational changes but in urban and industrial development. In addition, the revisionists dated the emergence of public schooling in the 2 decades before the Civil War and used the appointment of Horace Mann as the Secretary of the Massachusetts Board of Education in 1837 as a starting date (Bowles \& Gintis, 1976, p. 154).

There are numerous problems with the revisionist interpretation of the development of mass education and school reforms in 19th-century America. For one thing, it equated the movement for public school reforms in the $1840 \mathrm{~s}$ and 1850s with the expansion of mass education and did not look at developments outside Massachusetts.

Yet mass literacy and education in Massachusetts occurred well before the 1840 s and 1850 s. Lockridge (1974) documented that about $90 \%$ of men and $60 \%$ of New England women were literate by 1790 . According to the census figures on literary, only $1.1 \%$ of the White population, aged 20 years and older, in Massachusetts in 1840 were illiterate (Vinovskis, 1989). In addition, estimates of Massachusetts school attendance in 1800 indicate that it was already high in 1800 and gradually increased over the next 4 decades. Contrary to the interpretations of the revisionists, the percentage of children in Massachusetts schools actually decreased slightly from 1840 to 1850 (Kaestle \& Vinovskis, 1980).

There were important changes in some aspects of Massachusetts education in the $\mathbf{2}$ decades prior to the Civil War, such as the shift from private to public schools and the establishment of public high schools. But even here, 
one needs to acknowledge that some of these changes were a continuation of earlier trends. For example, the proportion of children in school receiving at least some private education dropped from $18.7 \%$ in 1840 to $8 \%$ in 1860 . Nevertheless, more than four of five students were already going to a public school in 1840, and therefore the major changes from private to public schooling occurred earlier (Vinovskis, 1989).

Another reason why the revisionist equation of the rise of mass education with industrialization is incorrect is that most of the expansion in schooling in the two decades prior to the Civil War occurred in areas which were predominantly rural and agricultural. The largest increases in the percentage of White children attending school or in the total number of new students between 1840 and 1860 was not in New England or in the Middle Atlantic states but in the North Central region (Fishlow, 1976).

If the revisionists exaggerated the causal relationship between the rise of mass education and industrialization, they overestimated the role of the manufacturers and merchants in achieving educational reforms (Bowles \& Gintis, 1976; Katz, 1968). While both of these groups generally supported the public school movement, they were less important than others, such as clergymen, at the local level (Vinovskis, 1985a). In addition, school reformers were active not only in the more industrialized states, such as Massachusetts, but in agricultural states, such as Michigan and Ohio. Nor were school reformers restricted to urban areas, as the revisionists imply. They were also present in rural communities, although in those communities, reformers often faced a different set of problems than in urban areas. Finally, rather than secing education imposed on an indifferent or hostile working class, as many revisionists believe, there is considerable evidence of widespread public support for education, including strong enthusiasm among Northern workers for common school education (Kaestle, 1983; Katznelson \& Weir, 1985).

Instead of seeing mass education as the result of mid-19th-century industrial development, it is more accurate to view it as a continuation of the colonial Puritan activities to ensure that everyone was able to read the Bible. This religious enthusiasm for education was reinforced by the establishment of the United States in the late 18th century and the extension of suffrage to almost all White adult males in the early 19th century. Given the perceived fragility of the early republic, mass public schools were seen as essential not only as a means of promoting widespread literacy but as a way of preserving moral values. As mothers were now regarded as the natural caretakers and educators of the next generation of citizens, women received access to public schooling that had been denied to most of them in the colonial period. Combined with a growing recognition in the 1840 s and 1850 s that education 
may foster individual social mobility and stimulate overall economic development, it is not surprising that mass public schooling for Whites expanded rapidly in all regions of the United States except the South, where geographic and social conditions limited the establishment and maintenance of common schools (Kaestle, 1983; Vinovskis, 1989).

\section{ANTEBELLUM VIEWS OF POVERTY AND EDUCATION}

Concern about poverty and disadvantaged children does not necessarily imply support for mass education. In early 19th-century England, a rapidly industrializing nation beset by problems of poverty and social unrest, calls for mass education encountered strong opposition. English opponents of education for the poor argued that schooling would encourage unrealistic occupational aspirations and lead to discontent among children of common laborers. They also feared that education would facilitate the dissemination of dangerous ideas against religion and civic authority (Silver, 1965).

There was almost no opposition to the education of poor Whites in the United States. Given the creation of the republic and the need for an educated electorate, conservatives supported schooling as a means of instilling proper values (Kaestle, 1976).

Although there was strong and widespread support for educating poor children in the United States, it was usually justified in terms of protecting society rather than of helping individuals get ahead. The value of education, according to most commentators, was to improve the moral character of the poor rather than to enhance their occupational skills or to foster individual social mobility. This orientation was due, in part, to the expectation that workers would acquire their specific job skills through apprenticeship instead of schooling (Rorabaugh, 1986).

Unlike today, 18th- and 19th-century British classical economists did not emphasize education as a key to individual or even societal economic productivity (Blaug, 1986). Adam Smith (1937), for example, briefly acknowledged that monetary rewards should compensate workers for acquiring skills, but he did not elaborate on the important implications of this insight. Most early 19th-century American political economists agreed, although some placed a little more emphasis on the benefits of education than did their British counterparts (Phillips, 1828; Wayland, 1843).

The leaders of the American workers in the 1820s and 1830s stressed the importance of universal common school education (Carlton, 1908) but paid scant attention to the value of education for enhancing economic productivity 
or fostering social mobility (Kaestle, 1983; Vinovskis, 1989). Instead, they saw in schooling a means of educating workers to recognize and protect their rights through the political process (Luther, 1832; Simpson, 1831).

The one person who did stress the economic productivity of education was Horace Mann. Responding to the legislative efforts to abolish the Massachusetts State Board of Education in 1840, Mann sought to broaden the support for public education by demonstrating its economic value to the state economy and to the individual in his Fifth Annual Report (Massachusetts Board of Education, 1842). Based on a flawed, but seemingly objective, survey of textile mill managers in Lowell, he argued that educated workers earned about $50 \%$ more than uneducated ones. Although Mann's estimate of the value of antebellum education was clearly exaggerated and based on faulty data and reasoning, it appeared scientific and plausible to his contemporaries (Vinovskis, 1970).

Thus while early 19 th-century Americans valued and promoted education, they usually did not acknowledge or emphasize its economic value for the individual or the society. Thanks to the work of Mann and his supporters, however, the economic productivity of elementary education was recognized and praised by the time of the Civil War. This reinforced the growing widespread belief in 19th-century America that the children of the poor could escape their poverty through education. Education became even more highly valued as an alternate means of occupational mobility, once other ways of training young people, such as apprenticeship, declined in early 19th-century America (Vinovskis, 1989).

\section{ANTEBELLUM PROGRAMS FOR EDUCATING POOR CHILDREN}

Did 19th-century Americans develop special educational programs to help poor children? And if programs for poor children were set up, were they altered over time to adjust to the development and changes in the common schools? To answer these and other related questions, we look at three antebellum educational programs: (a) monitorial charity schools, (b) Sunday schools, and (c) infant schools. Although these programs were not the only or even the most typical of antebellum efforts to educate children, they exemplify and illustrate how concerns about poverty and disadvantaged children were translated into special educational programs.

In the late 18 th and early 19 th centuries, efforts were made to establish charity schools for poor children in American cities. These institutions were 
intended for children whose parents were either incapable of educating their children at home or unable to enroll them in a private school. Many of these charity schools were sponsored and funded by religious groups, and they catered not only to poor White children but to free African-American children (Cremin, 1970).

\section{MONITORIAL CHARITY SCHOOLS}

Establishing and maintaining charity schools was expensive, and their philanthropic sponsors looked for ways to economize. One of the most promising and innovative approaches was to adopt the ideas and organization of Joseph Lancaster, a young English teacher who established monitorial (Lancasterian) schools for poor children in London and other communities in Great Britain. Lancasterian schools emphasized memorization and recitation and used older students to oversee and monitor the progress of younger ones (Kaestle, 1973).

Lancasterian schools quickly spread to the major urban areas in the United States in the 1810s and 1820s. The schools were efficient and economical and were usually organized on a nonsectarian basis. Students were allowed to progress at their own pace, and large numbers of poor children received their education in them.

Although American educators were at first enthusiastic about Lancasterian schools, complaints about the rote memorization and the impersonal education surfaced. As American school reformers of the 1830s and 1840s were exposed to the ideas of Johann Pestalozzi (Barlow, 1977), who stressed the need for more individual attention and for a close emotional relationship between the teacher and the pupil, the Lancasterian approach gradually fell out of favor and use.

The movement away from monitorial schools was reinforced by the growth of public schools and by the efforts to make these institutions attractive for children of middle-class families. Although the highly regimented and inexpensive Lancasterian schools were seen as adequate for poor children, they were viewed as inappropriate for middle-class children whose parents demanded a better education for their own children (Kaestle, 1973).

Poor children benefited by the abandonment of Lancasterian schools in the 1830 s and 1840 s because they were able to enroll in one of the smaller classes in public schools rather than being taught by older students in a large monitorial charity school. Nevertheless, for a few decades in the early 19th century, monitorial schools provided education for many disadvantaged children who might not have otherwise received any schooling. 


\section{SUNDAY SCHOOLS}

Sunday schools were another educational innovation intended for the poor which was borrowed from England (Laqueur, 1976). They were introduced into the United States in the 1790 s and proved to be equally popular here. Some of the first Sunday schools were set up in factory towns by industrialists, such as Samuel Slater, who wanted to provide schooling and religious training for poor children working in their textile mills (Tucker, 1984). As in England, religious activists played a key role in the establishment of Sunday schools in the larger cities, like Philadelphia, but initially these institutions were not controlled by or oriented toward a single religious denomination (Rice, 1917).

At first, Sunday schools emphasized teaching both poor children and illiterate adults how to read and encouraged the memorization of long passages from the Bible. Sunday schools often provided a basic education for those who were denied one elsewhere. Not surprisingly, many AfricanAmericans in northern cities received their limited education in them. In New York City, nearly $25 \%$ of the pupils in the Sunday School Union Society's institutions were African-Americans (Boylan, 1988).

As public common schools became more available and adult illiteracy declined, Sunday schools changed their clientele and goals. Fewer illiterate adults attended, and increasingly middle-class children attended the Sunday schools alongside the children of the poor. Because children now acquired reading and writing in the public schools, it was no longer necessary to teach literacy in the Sunday schools. Instead, by the 1830s, Sunday schools emphasized evangelical training and became a religious complement to the public schools (Boylan, 1988; Rice, 1917).

\section{INFANT SCHOOLS}

Monitorial and Sunday schools tried to educate poor children of all ages. But another institution, infant schools, was especially designed for young children as a means of overcoming their disadvantaged backgrounds. Although we often think that early childhood education for poor children originated in the mid-1960s, infant schools antedated the Head Start program by nearly 150 years.

Based on the pedagogical ideas of Pestalozzi and on Robert Owen's model infant school at New Lanark, Scotland, these institutions spread rapidly throughout Europe and America in the 1820s and early 1830s. Much of their popularity stemmed from the popular belief that by reaching disadvantaged 
children at the age of 2 or 3 years, it was possible to save them before they adopted the harmful habits and dangerous values of their impoverished environment (Whitbread, 1972).

Early 19th-century Americans believed that children were capable of intellectual development at an early age. Therefore, the idea of special infant schools for children of poor parents seemed reasonable and natural. Because the educational practices in infant schools ranged from allowing the children to play to teaching them to read, there was widespread agreement that educating poor young children helped them to overcome their disadvantaged backgrounds (May \& Vinovskis, 1977).

Although infant schools initially were intended for poor children, once middle-class families heard about them, they feared that the poor in infant schools might gain an advantage over their own children. As a result, middle-class parents wanted these institutions made available to all children.

Infant schools and early childhood education spread rapidly in the United States. Although, at first, infant schools were set up only in the larger urban areas like Boston, New York, and Philadelphia, many rural communities established them. It is estimated that in 1840 approximately $40 \%$ of all 3-year-olds in Massachusetts were either enrolled in a special infant school or in a regular common school (Kaestle \& Vinovskis, 1978).

Despite the initial enthusiasm for infant schools by parents and educators, they did not last long. In 1833, Amariah Brigham, a prominent physician, argued that early intellectual activity among children weakens the development of the brain and eventually may lead to insanity (Brigham, 1833, p. 15).

Brigham's ideas, based on the best medical and scientific thinking of the day, were widely disseminated among middle-class families through popular magazines. Support for infant schools and early childhood education quickly faded, and by 1860 , there were almost no children under the age of 5 years in Massachusetts public schools (May \& Vinovskis, 1977). What had started out as a means of helping poor children overcome their deficient home environments was now seen as detrimental to any young children in school. Middle-class parents were more likely than lower-class ones to withdraw their own children from the infant schools, partly because they were more likely to read about the injunctions against early education in popular magazines and advice books. But once philanthropic support and public funds were withheld from the infant schools and educational authorities barred very young children from entering public schools, the early schooling for all antebellum children in America collapsed (Kaestle \& Vinovskis, 1978). 


\section{SUMMARY}

Having examined monitorial charity schools, Sunday schools, and infant schools, it is clear that antebellum Americans did set up special educational programs for poor and disadvantaged children. Their motivations were mixed. Some feared the social and economic disruptions caused by urbanization and industrialization and believed that educating poor children would help to minimize these difficulties. Others were more concerned about the political stability and felt that an educated electorate was essential in the new republic. Many philanthropists and educational reformers were genuinely concerned about the well-being of disadvantaged children and felt it was their religious duty to help those less fortunate than themselves.

Many of the educational efforts aimed at poor children originated abroad and came to the United States from Great Britain. Indeed, historians have often ignored or minimized the importance of the transmission of ideas and institutions from abroad by viewing American developments in isolation from other countries. Yet the establishment and growth of educational institutions for the poor in the United States was not identical to that of comparable programs in Great Britain. With virtually no opposition to the education of the poor Whites in 19th-century America, it was much easier to promote such innovations here than in England, where strong opposition to mass public education persisted.

Educational programs for the poor in the United States frequently started out as private, charitable efforts in the early 19 th century but quickly sought and received public funding. Indeed, one of the interesting characteristics of many of these programs is that they shifted from efforts aimed exclusively at poor and disadvantaged children to ones intended for everyone.

There were many advantages to having educational programs designed for the poor expanded to include all children. The stigma attached to attending private charity schools was largely eliminated once these institutions became public schools intended for middle-class as well as lower-class children. The quality of the education in these institutions also often improved because middle-class parents insisted on better facilities and teachers once their own children were affected. But there were also some disadvantages for poor children which did not receive much attention at the time. Once schools were intended for everyone and not just poor children, 19th-century reformers usually assumed that disadvantaged children in the public common schools did not need any special help or guidance. Indeed, as was seen in the case of infant schools, there was concern among middle-class parents that any special efforts on behalf of the poor might actually disadvantage their own children. As a result, the focus of much of 19 th-century educational 
reforms were on getting poor children into public common schools rather than in looking for ways of helping poor children once they had enrolled.

Finally, although there was little distinction by gender, the special educational programs for poor children in antebellum America were intended mainly for Whites. African-American children usually did not receive equal access either to these special programs or to the regular public common schools. Sometimes, separate monitorial charity schools, Sunday schools, or infant schools were established in large cities for African-American children, but not often. In the North, African-American children faced strong racial prejudices and often segregated schools that limited their education in antebellum America. With the increased fear of abolitionists and slave revolts in the 1830s and 1840 s, Southern states tried to restrict education for their slaves. As a result, African-American children in antebellum America, who were clearly among the most disadvantaged individuals in that society, did not receive equal access to schooling.

\section{POOR CHILDREN AND SCHOOL ATTENDANCE IN 1860}

Despite the availability of public common schools, especially in the Northeast and the Midwest, were most poor children able to attend, or were they forced into the labor force because of poverty? To answer this question, we look at Massachusetts, a state where public schools were well-developed and where several scholars have investigated patterns of school attendance in 1860 using individual-level census data.

Most analysts agree that by 1860 almost every child in Massachusetts, including those from poor or working-class families, received some common school education. During their teens, however, children from poor or workingclass families were more likely to drop out of school than were those from wealthy or middle-class families (Katz, 1987; Katznelson \& Weir, 1985).

The classic and still most frequently cited study of school attendance of poor children in antebellum America is Thernstrom's (1964) analysis of Newburyport, Massachusetts. He analyzed the lives of common laborers in that community in 1860 and concluded that poverty forced almost all of their children to drop out of school at an early age.

Thernstrom's pessimistic portrayal of school attendance among children of the working class in antebellum Newburyport is exaggerated and incorrect. Based on a more detailed statistical manuscript census analysis of all 13,000 residents of Newburyport in 1860 rather than of the 400 common laborers in Thernstrom's study, lower-class children received more schooling in that 
community than Thernstrom believed. Thernstom said that the chances of school attendance of an 11- or 12-year-old, whose father was a common laborer, were nil, but a statistical reexamination found that over $90 \%$ of them were still in school (Vinovskis, 1985b).

Were the patterns of school attendance in Newburyport similar to those in other Massachusetts communities? Another individual-level manuscript census study of Lawrence, Lynn, Salem, and five other smaller communities in Essex County in 1860 produced similar results, although a somewhat lower overall rate of school attendance (Kaestle \& Vinovskis, 1980).

If most antebellum poor children in Massachusetts received at least some common school education, and many remained in school as teenagers, did they also have access to the newly created public high schools? Again, the consensus among historians is that few public high schools existed in the 19th century and the small number that were established served almost entirely children from the middle or upper classes (Krug, 1969; Peterson, 1985).

Public high schools were certainly rare in antebellum America, but in some areas of the county, such as Massachusetts, they were more commonplace. Nor were high schools confined only to large urban cities like Boston, New York, and Philadelphia; they also existed in smaller communities. In most large cities, there was only one high school, and hence only a small percentage of children could ever attend. In the smaller communities with high schools, however, a much higher proportion of children enrolled. An analysis of high school attendance in Essex County, Massachusetts in 1860 found that a substantial minority of youths passed through such an institution. Combining both public high schools and comparable private academies, $19 \%$ of Essex County children received at least some high school education. However, because most students entering high school did not stay long enough to complete the degree, it is not clear exactly what benefits, if any, came from a limited exposure to secondary schooling (Vinovskis, 1988).

Were children of working-class families in effect excluded from public high school education, as some historians have argued? Not entirely. Although children whose parents were wealthier and in white-collar occupations were more likely to attend high school, some children from poor families also enrolled. In Newburyport, almost a third of all children in 1860 enrolled at some time in one of the local public or private high schools, and $30.8 \%$ of them graduated. Although two thirds of those attending high school were children whose fathers were in high white-collar occupations, about one third of those whose fathers were in skilled occupations and one sixth of those whose fathers were in unskilled occupations also enrolled (Vinovskis, 1985b).

This detailed examination of the patterns of elementary and secondary school attendance has been confined to Massachusetts, a state with well- 
developed common and high schools. Although the overall levels of antebellum school attendance would be somewhat lower in the Midwest, the same general patterns appear. Only in the South, where the common schools were slow in developing, might one anticipate much lower rates of school attendance and perhaps more of a differential in education between children from poor and more affluent families. Finally, we need to remind ourselves that while many poor White children had considerable access to public and private schooling, the same was not true for African-American children (Kaestle, 1983).

\section{EDUCATION AND SOCIAL MOBILITY AMONG POOR CHILDREN}

Was social mobility possible in 19 th-century America? According to popular thought, everyone had an opportunity to get ahead through hard work and some luck. As was noted earlier, education was not always seen as a key factor in social mobility, but good habits and character were considered essential.

But was there real social mobility for 19th-century Americans if we look at their behavior rather than their beliefs? This is a very complicated issue, as it depends on one's definition of social mobility and which particular case studies were used.

The findings of social mobility studies of 19 th-century Americans were mixed when we look at those near the bottom of the occupation structure (unskilled or semiskilled). Overall, it appears that most unskilled or semiskilled workers or their children were able to improve slightly their occupational standing and/or to purchase their own home. It was much less likely, however, that either unskilled or semiskilled workers would move directly into high or low white-collar positions, although their children were more likely to do so. Surprisingly, there was little difference between America and Europe in regard to overall career mobility, but there was slightly more upward mobility among unskilled workers in the United States than in Europe (Kaeble, 1985).

But was education a key factor in fostering social mobility among unskilled or semiskilled workers and their children? According to most revisionists, the answer is clearly no (Graff, 1979, pp. 114-115; Katz, Doucet, \& Stern, 1982, p. 275).

On the other hand, scholars, such as Thernstrom (1964), have implicitly assumed in their studies that education was a major factor in social mobility in the 19 th century. Unfortunately, most of the early studies of the relationship 
between education and social mobility in 19th-century America are so flawed methodologically that one cannot draw any reliable conclusions from them (Vinovskis, 1989).

Recently, several studies have appeared, including some by a conceptually and methodologically more sophisticated new generation of revisionist scholars, that address the relationship between education and social mobility. Whereas earlier scholars, such as Bowles and Gintis (1976), argued that schools simply reproduced the existing capitalist structure by excluding children of working-class families from them and then discriminating against the few who did enter, Labaree's (1988) study of Philadelphia's Central High School found that once students were admitted, they found themselves "in a model meritocracy where academic performance was the only characteristic that determined who would receive the school's valuable diploma" (p. 37).

If Labaree's study demonstrated that working-class children, once admitted to a high school, could do just as well as middle-class children, what about their subsequent occupation mobility? Unfortunately, his study of Philadelphia's Central High School did not trace the students to their jobs, but Ueda's (1987) analysis of the intergenerational mobility of grammar and high school students in Somerville, Massachusetts in the second half of the 19 th century did. Ueda discovered that blue-collar sons who went to high school did better than those who did not.

The most sophisticated study of late 19th-and early 20th-century social mobility is Perlmann's (1985, 1988) logit analysis of schooling and occupational achievement in Providence, Rhode Island between 1880 and 1935. Even after controlling for the effects of family background, Perlmann found that for most children, some high school education (but not necessarily having graduated) was a great advantage occupationally.

A high school education was not equally useful for everyone in Providence. Perlmann found that whereas White children of poor and immigrant parents benefited from entering high school, African-American children who received some high school education still faced almost insurmountable racial job discrimination. As a result, although many African-American children in Providence attended the high school and did well academically, education by itself was not sufficient to overcome the racial barriers to their social mobility.

\section{CONCLUSION}

Americans have always been concerned about poor and disadvantaged children, but the ways in which they have tried to help them have varied 
considerably. Part of the 19th-century concern about poor children was due to a fear of what would happen to society if the next generation did not share its values and goals. Part of Americans' interest also grew out of Christian benevolence toward less fortunate individuals. Whatever the source of that concern, and it was complex and mixed even for the same individuals within that society, there was general agreement that it was easier to change the young child than reform the adult. Most 19th-century Americans also saw education as an effective means for guiding and controlling the development of disadvantaged children into productive citizens.

Colonial and 19th-century Americans believed that the primary responsibility for education rested with the parents. Over time, private and public schools were acknowledged as substitutes for inadequate training at home, but these institutions were never seen as a total replacement for the family. Instead, in the 19th century, the family and the schools were each expected to play an important role in the upbringing and socialization of the child.

Today, we need to return to the idea that both the family and the schools have an important responsibility in the education of our children. Compared to our colonial or 19th-century ancestors, most parents today neglect their responsibility and role as educators in the home. Also, many education policymakers, while acknowledging the importance of the family, often do very little to foster parental involvement with their children's education (especially in the junior and senior high schools). Although we should not idealize parental participation in education in the past, at least it was a goal commonly accepted by 19 th-century Americans, although not always put into practice.

Nineteenth-century Americans also established special educational programs for poor children. We have seen how monitorial charity schools, Sunday Schools, and infant schools were designed to help poor children overcome their disadvantaged family backgrounds. Rather than isolating the poor within these programs, efforts later were made to integrate poor and middle-class children in public schools. Although we should not always applaud the results of their efforts (especially in those cases of late 19thcentury tracking, where poor children were systematically excluded from more academically oriented training), on the whole, children from poor and disadvantaged backgrounds often received classroom education roughly comparable to their more fortunate compatriots, especially since the more rigid neighborhood segregation by class and wealth occurred only after the Civil War.

Nineteenth-century Americans were open to new ideas about programs to help educate poor children and frequently borrowed ideas and models from other countries. Today, we need to recapture that openness and experiment 
more with alternative ways of helping disadvantaged children through our schools. We also need more awareness of comparable educational efforts in other countries, such as Japan and Germany, and a willingness to learn from their school programs. We cannot afford to be as insular and provincial in our educational knowledge and policies as we have become since the 19th century.

Most 19th-century Americans believed that those who were hard-working, but came from disadvantaged backgrounds, could succeed. Although their faith in the openness of their society was exaggerated and did not pay enough attention to the structural components of inequality, it did foster a climate of opinion in which individuals were led to believe that all people could succeed through their own efforts. Today, while acknowledging and working to eliminate the structural impediments to social mobility, we also must stress the importance of individual and family efforts in getting ahead in our society. Thus the recent educational successes of the children of the "boat people" provide testimony to the role of family and cultural values in motivating disadvantaged students to excel in schools.

Surprisingly, most early 19th-century Americans did not emphasize education as a key either to individual success or to the growth of the economy. Only after the efforts of Horace Mann and others in the 1840s and 1850s was our current notion that education is central to growth of the economy explored and publicized. But they did recognize the importance of moral and character development in building good citizens and workers. Today, in our own discussions of the economic productivity of education, we often fail to acknowledge the importance that values and character play in preparing the next generation.

Contrary to the strong and often cited claims of the revisionists of the 1960s and 1970s, it does appear that schooling in 19th-century America promoted individual social mobility. Although so far there are few methodologically sound studies on this issue and almost all of them are confined to students who entered high schools, the weight of the evidence suggests that schooling in the past did matter. This is not to imply that children of poor parents were not disadvantaged - they clearly were. Nor does it imply that schools could overcome all of the disadvantages of poverty for the individual. It does, however, suggest that schools did more than just reproduce the existing capitalist structure - they also provided some real opportunities for advancement for those poor children able to take advantage of them.

Finally, schooling by itself is of limited value if society refuses to acknowledge and reward those with better educational preparation and training. Unless successful students in school have equal or near equal access 
to better jobs and the other material rewards of our society, any advantages conferred by further schooling will be quickly lost. African-Americans in the 19 th century faced not only discrimination in schooling but even those who were educated could not compete effectively with Whites in the labor force. As a result, the great enthusiasm and interest in public schooling among African-Americans after the Civil War began to wane by the early 20th century once they realized that education had little impact on their subsequent occupational opportunities. Therefore, current educational campaigns to help poor and disadvantaged students must be accompanied by serious and sustained efforts to eliminate any remaining discrimination in our society on the basis of class, ethnicity, race, or gender.

Although this review of 19th-century efforts to help poor and disadvantaged children through schooling does not and cannot lead to any simple or mechanical prescription for how to organize or implement comparable programs today, it should reinforce our commitment to helping disadvantaged children through our schools. Education has in the past played an important complementary role in our efforts to help poor children have equal access to the full range of opportunities in our society. 1 think it can continue to do so today.

\section{REFERENCES}

Bailyn, B. (1960). Education in the forming of American society. Chapel Hill: University of North Carolina Press.

Barlow, T. A. (1977). Pestalozzi and American eduation. Boulder, CO: Este Es Press.

Blaug, M. (1986). Economic history and the history of economics. New York: New York University Press.

Bowles, S., \& Gintis, H. (1976). Schooling in capitalist America: Education reform and the contradictions of economic life. New York: Basic Books.

Boylan, A. M. (1988). Sunday school: The formation of an American institution, 1790-1880. New Haven, CT: Yale University Press.

Brigham, A. (1833). Remarks on the influence of mental cultivation and mental excitement upon health (2nd ed.). Boston: Marsh, Capen, \& Lyon.

Carlton, F. T. (1908). Economic influences upon educational progress in the United States, 1820-1850. Madison: University of Wisconsin Press.

Cohen, S. (1974). A history of colonial education, 1607-1776. New York: Wiley.

Cremin, L. A. (1970). American education: The colonial experience, 1607-1783. New York: Harper \& Row.

Fishlow, A. (1976). The American common school revival: Fact or fancy? In H. Rosovsky (Ed.), Industrialization in two systems: Essays in honor of Alexander Gershenkron (pp. 40-67). New York: Wiley.

Graff, H. J. (1979). The literacy myth: Literacy and social structure in the nineteenth-century city. New York: Academic Press. 
Jencks, C. (1979). Who gets ahead? The determinants of economic success in America. New York: Basic Books.

Kaeble, H. (1985). Social mobility in the nineteenth and twentieth centuries: Europe and America in comparative perspective. Leamington Spa, England: Berg.

Kaestle, C. F. (1973). Joseph Lancaster and the monitorial school movement: A documentary history. New York: Teachers College Press.

Kaestle, C. F. (1976). Between the Scylla of brutal ignorance and the Charybdis of a literary education: Elite attitudes toward mass schooling in early industrial England and America. In L. Stone (Ed.), Schooling and society: Studies in the history of education (pp. 177-191). Baltimore: Johns Hopkins University Press.

Kaestle, C. F. (1983). Pillars of the republic: Common schools and American society, 1780-1860. New York: Hill \& Wang.

Kaestle, C. F., \& Vinovskis, M. A. (1978). From apron strings to ABCs: Parents, children, and schooling in nineteenth-century Massachusetts. In J. Demos \& S. S. Boocock (Eds.), Turning points: Historical and sociological essays on the family (pp. 39-80). Chicago: University of Chicago Press.

Kaestle, C. F., \& Vinovskis, M. A. (1980). Education and social change in nineteenth-century Massachusetts. Cambridge: Cambridge University Press.

Katz, M. B. (1968). The irony of early school reform: Educational innovation in mid-nineteenthcentury Massachusetts. Cambridge, MA: Harvard University Press.

Katz, M. B. (1975). Class, bureaucracy \& schools: The illusion of educational change in America. New York: Praeger.

Katz, M. B. (1987). Reconstructing American education. Cambridge, MA: Harvard University Press.

Katz, M. B., Doucet, M. J., \& Stern, M. J. (1982). The social organization of early industrial capitalism. Cambridge, MA: Harvard University Press.

Katznelson, I., \& Weir, M. (1985). Schooling for all: Class, race, and the decline of the democratic ideal. New York: Basic Books.

Krug, E. A. (1969). The shaping of the American high school, 1880-1920. Madison: University of Wisconsin Press.

Labaree, D. F. (1988). The making of an American high school: The credentials market and the Central High School of Philadelphia, 1838-1939. New Haven, CT: Yale University Press.

Laqueur, T. W. (1976). Religion and respectability: Sunday schools and working class culture, 1780-1850. New Haven, CT: Yale University Press.

Lockridge, K. A. (1974). Literacy in colonial New England: An enquiry into the social context of literacy in the early modern West. New York: Norton.

Luther, S. (1832). An address to the working-men of New England, on the state of education, and on the condition of the producing classes in Europe and America. Boston: Seth Luther.

Massachusetts Board of Education. (1842). Fifth annual report of the Board of Education together with the fifth annual report of the secretary of the Board. Boston: Dutton \& Wentworth.

May, D., \& Vinovskis, M. A. (1977). A ray of millenial light: Early education and social reform in the infant school movement in Massachusetts, 1826-1840. In T. K. Hareven (Ed.), Family and kin in urban communities (pp. 62-99). New York: New Viewpoints.

Moran, G. F., \& Vinovskis, M. A. (1986). The great care of godly parents: Early childhood in Puritan New England. In A. B. Smuts \& J. W. Hagen (Eds.), History and research in child development (pp. 24-37). Chicago: University of Chicago Press.

Murphy, J. G. (1960). Massachusetts Bay Colony: The role of government in education. Unpublished doctoral dissertation, Radcliffe College. 
Perlmann, J. (1985). Who stayed in school? Social structure and academic achievement in determination of enrollment patterns, Providence, Rhode Island, 1880-1925. Journal of American History, 72, 588-614.

Perlmann, J.(1988). Ethnic differences: Schooling and social structure among the Irish, Italians, Jews, and Blacks in the American city, 1880-1935. Cambridge: Cambridge University Press.

Peterson, P. E. (1985). The politics of school reform, 1870-1940. Chicago: University of Chicago Press.

Phillips, W. (1828). A manual of political economy with particular reference to the institutions, resources, and condition of the United States. Boston: Hilliard, Gray, Little, \& Wilkins.

Rice, E. W. (1917). The Sunday-school movement, 1780-1917, and the American Sunday School Union, 1817-1917. Philadelphia: American Sunday-School Union.

Rorabaugh, W. J. (1986). The craft apprentice: From Franklin to the machine age in America. New York: Oxford University Press.

Silver, H. (1965). The concept of popular education: A study of ideas and social movements in the early nineteenth century. London: MacGibbon \& Kee.

Simpson, S. (1831). The working man's manual: A new theory of political economy, on the principle of production the source of wealth. Philadelphia: Bonsal.

Smith, A. (1937). An inquiry into the nature and causes of the wealth of nations. New York: Modern Library.

Thernstrom, S. (1964). Poverty and progress: Social mobility in a nineteenth-century city. Cambridge, MA: Harvard University Press.

Tucker, B. (1984). Samuel Slater and the origins of the American textile industry. Ithaca, NY: Cornell Universily Press.

Ueda, R. (1987). Avenues to adulthood: The origins of the high school and social mobility in an American suburb. Cambridge: Cambridge University Press.

Vinovskis, M. A. (1970). Horace Mann on the economic productivity of education. New England Quarterly, 43, 550-571.

Vinovskis, M. A. (1985a). The origins of public high schools: A re-examinaiton of the Beverly High School controversy. Madison: University of Wisconsin Press.

Vinovskis, M. A. (1985b, December). Patterns of high school attendance in Newburyport, Massachusetts in 1860. Paper presented at the annual meeting of the American Historical Association, New York City.

Vinovskis, M. A. (1987). Family and schooling in colonial and nineteenth-century America. Journal of Family History, 12, 19-37.

Vinovskis, M. A. (1988). Have we underestimated the extent of antebellum high school attendance? History of Education Quarterly, 28, 551-567.

Vinovskis, M. A. (1989). The role of education in the economic transformation of nineteenthcentury America. In S. Berryman (Ed.), Education and the economy: Hard questions, hard answers. New York: National Center for Education and Employment Conference Papers.

Wayland, F. (1843). The elements of political economy (4th ed.). Boston: Gould, Kendall, \& Lincoln.

Whitbread, N. (1972). The evolution of the nursery-infant school: $A$ history of infant and nursery education in Britain, 1800-1970. London: Routledge \& Kegan Paul. 